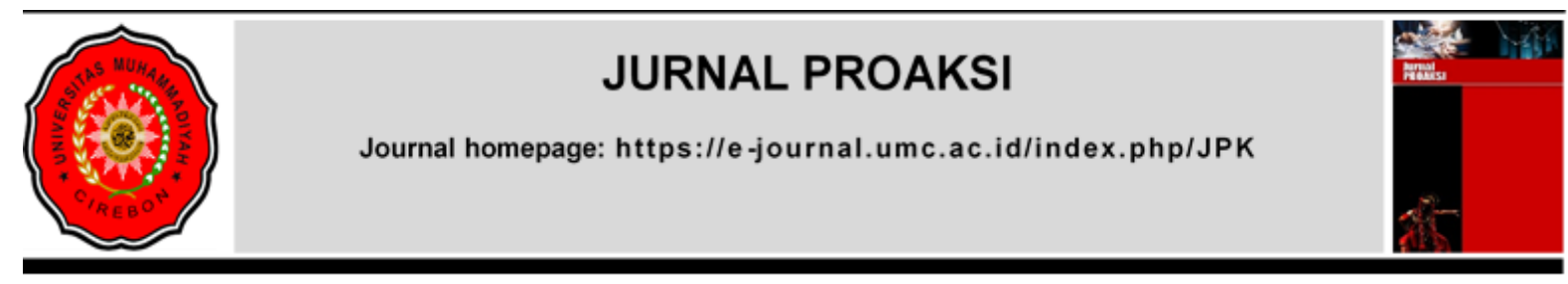

\title{
FAKTOR-FAKTOR YANG MEMPENGARUHI KINERJA KEUANGAN PADA PERUSAHAAN PERTAMBANGAN DI BURSA EFEK INDONESIA
}

\author{
Laelatun Mazaya ${ }^{1}$ \\ Endah Susilowati ${ }^{2}$ \\ ${ }^{1}$ Fakultas Ekonomi dan Bisnis, Universitas Pembangunan Nasional "Veteran" Jawa Timur \\ Email : mayamazaya6@gmail.com \\ ${ }^{2}$ Fakultas Ekonomi dan Bisnis, Universitas Pembangunan Nasional "Veteran" Jawa Timur \\ Email : endahs.ak@upnjatim.ac.id
}

Diterima : 22 Juli 2021

Direvisi : 5 Agustus 2021

Dipublikasikan : 4 Desember 2021

\begin{abstract}
Abstrak
Perkembangan dunia bisnis yang semakin pesat diiringi dengan persaingan yang ketat, menjadikan perusahaan harus mampu untuk bertahan salah satunya dengan meningkatkan kinerja keuangan. Perusahaan sektor pertambangan merupakan salah satu penopang pembangunan ekonomi social. Namun dalam kurun waktu lima tahun terakhir perusahaan sektor pertambangan mengalami fluktuasi dalam perolehan laba perusahaan sehingga menyebabkan turunya kinerja keuangan perusahaan. Penelitian ini dilakukan untuk menguji pengaruh intellectual capital, competitive advantage, struktur modal, ukuran perusahaan dan pertumbuhan perusahaan terhadap kinerja keuangan pada perusahaan sektor pertambangan di BEI. Terdapat 47 populasi perusahaan sektor pertambangan yang terdaftar di BEI. Sampel penelitian ini sejumlah 65 laporan keuangan perusahaan yang diperoleh dengan menggunakan metode purposive sampling. Teknik analisis yang digunakan adalah Partial Least Square (PLS) dengan alat bantu SmartPLS 3.0. Hasil penelitian menunjukkan bahwa intellectual capital tidak berpengaruh terhadap kinerja keuangan, struktur modal tidak berpengaruh terhadap kinerja keuangan, ukuran perusahaan berpegaruh terhadap kinerja keuangan dan pertumbuhan perusahaan tidak berpengaruh terhadap kinerja keuangan.
\end{abstract}

Kata Kunci : Aset, Laba, Modal, Kinerja Keuangan

\section{PENDAHULUAN}

Semakin ketatnya perkembangan pada dunia bisnis yang diikuti dengan persaingan usaha semakin pesat dengan didukung oleh kemajuan teknologi informasi, komunikasi dan perusahaan secara global yang semakin berkembang pesat sehingga setiap perusahaan wajib mempersiapkan diri untuk menghadapi persaingan bisnis dengan memiliki pegangan tujuan yang harus jelas agar mampu mempertahankan perusahaan dan menjaga kelangsungan hidup perusahaannya. Dalam perusahaan untuk menghadapi persaingan bisnis perlu meningkatkan strategi dan inovasi untuk mencapai tujuan dan kinerja perusahaan. Perusahaan harus mampu memaksimalkan kinerja keuangannya agar dapat mencapai segala tujuan perusahaan dengan meningkatkan kemakmuran pemilik maupun pemegang saham dapat mempertahankan kelangsungan hidup perusahaan (Wiyono, Gendro dan Kusuma, 2017) Beberapa perusahaan yang telah go public berlomba-lomba untuk dapat meningkatkan nilai perusahaan, perusahaan yang memiliki nilai yang tinggi dianggap dapat memaksimalkan kekayaan para pemegang saham. Jika harga saham tinggi, maka nilai perusahaan tersebut akan tinggi dan hal ini mencerminkan tingkat kepercayaan investor yang tinggi pada perusahaan yang mengeluarkan saham tersebut (Wiagustini, 2010)

Menerapkan sebuah strategi yang memanfaatkan sumber daya perusahaan dibutuhkan Resource Based Theory (RBT). RBT terbatas hanya pada sumber daya statis seperti jumlah secara kuantitas 
sumber daya yang dimiliki perusahaan, dan tidak mampu dalam mendefinisikan pertambahan nilai dari sumber data yang intangible (tak berwujud) yang dimiliki perusahaan. Jika dilihat dari Intellectual Capital dianggap mampu membantu dan mendeskripsikan pengukuran pertambahan nilai yang dihasilkan oleh sumber daya yang tak terwujud agar dapat meningkatkan kinerja perusahaan. Tujuan dari pengukuran kinerja keuangan yaitu agar mengetahui tingkat likuiditas perusahaan dan mengetahui tingkat solvabilitas, rentabilitas atau profitabilitas dan stabilitas perusahaan, sehingga pengukuran kinerja keuangan dapat memberikan penilaian atas pengelolaan aset perusahaan yang digunakan untuk bahan evaluasi bagi manajemen perusahaan untuk melakukan perbaikan-perbaikan atas kurangnya kinerja perusahaan. Parameter yang digunakan dalam pengkuran kinerja keuangan dilihat dari laba perusahaan tersebut. Jika pertumbuhan laba semakin baik atau meningkat maka akan mengindentifikasi bahwa perusahaan tersebut semakin baik.

Sektor pertambangan memiliki potensi pertumbuhan yang tinggi karena melonjaknya permintaan akan komoditas tambang salah satunya nikel dan timah. Selain itu sektor pertambangan juga mempunyai tingkat resiko yang tinggi. Kinerja keuangan yang dilihat di laporan keuangan akan dinilai oleh investor untuk dipertimbangkan dan melakukan analisa kinerja keuangan untuk mengambil keputusan dalam melakukan investasi di perusahaan tersebut. Penilaian kinerja keuangan perusahaan dapat dirumuskan dengan Return on Asset (ROA) dan Return on Equit (ROE). Usaha yang dilakukan oleh perusahaan untuk meningkatkan kinerja keuangan dengan mengefisiensikan faktor-faktor yang mempengaruhi kinerja keuangan yang terfokuskan pada pemanfaatan sumber daya yang dimiliki oleh perusahaan. (Dimas, 2020) menyatakan bahwa sejumlah perusahaan batubara masih konsisten untuk menjaga tren pertumbuhan kinerja dalam lima tahun terakhir, meskipun bergerak secara fluktuatif dan dinamis.

Menurut (Munawir, 2012) tujuan dari pengukuran kinerja keuangan adalah untuk mengetahui tingkat likuiditas perusahaan, mengetahui tingkat solvabilitas, mengetahui tingkat rentabilitas atau profitabilitas, mengetahui tingkat stabilitas perusahaan. Sehingga dapat disimpulkan bahwa pengukuran kinerja keuangan dapat memberikan penilaian atas pengelolaan asset perusahaan yang digunakan sebagai bahan evaluasi bagi manajemen perusahaan untuk melakukan tindakan perbaikan atas kinerja keuangan perusahaan yang tidak sehat. Oleh karena itu kinerja keuangan menjadi perhatian penting dalam pertumbuhan perusahaan karena perusahaan yang tumbuh dengan cepat akan memperoleh hasil yang optimal sehingga mampu meningkatkan penjualan, harga pasar dan dapat menarik investor dalam berinvestasi di perusahaant tersebut.

Tujuan dilakukanya penelitian ini adalah (1) menguji dan menganalisis pengaruh intellectual capital terhadap kinerja keuangan pada perusahaan sektor pertambangan di BEI tahun 2015 - 2019, (2) menguji dan menganalisis pengaruh competitive advantage terhadap kinerja keuangan pada perusahaan sektor pertambangan di BEI tahun 2015 - 2019, (3) menguji dan menganalisis pengaruh struktur modal terhadap kinerja keuangan pada perusahaan sektor pertambangan di BEI tahun 2015 - 2019, (4) menguji dan menganalisis pengaruh ukuran perusahaan terhadap kinerja keuangan pada perusahaan sektor pertambangan di BEI tahun 2015 - 2019, (5) menguji dan menganalisis pengaruh pertumbuhan perusahaan terhadap kinerja keuangan pada perusahaan sektor pertambangan di BEI tahun 2015 - 2019 .

\section{KAJIAN PUSTAKA \\ Resources Based Theory (RBT)}

Resources Based Theory (RBT) merupakan teori yang membahas mengenai kepemilikan sumber daya perusahaan dan bagaimana perusahaanmampu mengelola sumber daya tersebut. (Wijayani, 2017) menjelaskan bahwa Resources Based Theory (RBT) pertama kali diperkenalkan oleh (Wernefelt, 1984) dalam artikelnya menyatakan RBT merupakan sumber daya yang terdapat pada perusahaan yang dapat disajikan keunggulan bersaing dan mampu mengarahka perusahaan untuk memiliki kinerja jangka yang baik.

\section{Agency Theory}

Agency Theory yaitu teori yang menjelaskan hubungan pemilik perusahaan dalam menyerahkan pengelolaan perusahaan kepada tenaga professional atau agen yang lebih ahli dalam mengelola operasional perusahaan. Dijelaskan bahwa hubungan keagenan sebagai hubungan yag timbul karena adanya perjanjian yang dilakukan pemilik perusahaan atau pemegang saham yang menggunakan agen untuk melakukan jasa yang menjadi kepentingan pemilik, hal ini secara tidak langsung terjadi 
pemisahan dan pengendalian perusahaan yang mengakibatkan perusahaan terbagi menjadi dua kelompok yaitu pemilik perusahaan dan agen yang masing-maisng memiliki hak dan kewajiban serta memiliki kepentingan yag berbeda jika tidak disatukan persepsi tujuannya (Jensen, M., C., 1976).

\section{Kinerja Keuangan}

(Sucipto, 2003) Kinerja keuangan adalah penentuan ukuran-ukuran tertentu yag dapat mengukur keberhasilan suatu organisasi atau perusahaan dalam menghasilkan laba. Kinerja perusahaan sebagai gambaran tentang kondisi perusahaan dilihat dari analisis keuangan sehingga dapat diketahui baik buruknya kondisi perusahaan pada periode tertentu yang menunjukka prestasi kerja perusahaan. Hal ini agar sumber daya pada perusahaan tersebut dapat digunakans ecara optimal dalam menghadapi persaingan dan perubahan lingkungan. (Brigham \& Huston, 2010) Analisis terhadap laporan keuangan meliputi :

1. Membandingan kinerja perusahaan dengan perusahaan lain dalam industri yang sama.

2. Evaluasi kecenderungan posisi keuangan perusahaan sepanjang waktu.

\section{Intellectual Capital}

(Cheng, Lin, Hsiao, \& Lin, 2010) Intellectual Capital adalah sumber daya kunci pergerak dalam kinerja serta penciptaan nilai perusahaa, sehingga hal tersebut berperan penting dalam menciptakan dan mempertahankan keunggulan kompetitif. Intellectual Capital termasuk dalam aset tidak berwujud yang berkaitan dengan ilmu pengetahuan, wawasan dan kemampuan sumber daya manusia juga sistem teknologi yang ada dalam (Porter, 2007) perusahaan. Hal ini mempunyai potensi yang baik untuk dapat meningkatkan keuunggulan bersaing bagi perusahaan.

\section{Competitive Advantage}

Persaingan bisnis pasti dihadapi di setiap perusahaan, untuk menghadapi persaingan tersebut membutuhkan persiapan yang lebih unggul dari perusahaan lain. Keunggulan yang tinggi pada perusahaan dipengaruhi oleh sumber daya yang dimiliki oleh perusahaan. (Porter, 2007). Competitive Advantage memberikan gambaran untuk perusahaan dalam mencari dan menerapkan strategi untuk meningkatkan dan mempertahankan persaingan di perusahaan. (Barney, 2010) melakukan penyelidikan terhadap sumer daya perusahaan dan keunggulan bersaing yang berkesinambungan melalui empat indikator yaitu : value, rareness, imitability dan substitutability.

\section{Struktur Modal}

(Fahmi, 2017) Strukur Modal adalah gambaran dari bentuk proporsi finansial perusahaan yaitu antara modal yang dimiliki bersumber dari hutang jangka panjang dan modal senidi yang menjadi sumber pembiayaan suatu perusahaan. (Sudana, 2015) hal ini berkaitan dengan pembelanjaan jangka panjang suatu perusahaan yang diukur dengan perbandingan utang jangka panjang dengan modal sendiri. Penelitian ini dihitung dengan Debt to Equity Ratio (DER). Rasio ini dipandang dapat menggambarkan sumber pendanaan perusahaan dengan pertimbangan bahwa semakin besar total hutang maka akan semakin tinggi risiko yang akan kebnagkrutan.

\section{Ukuran Perusahaan}

(Jogiyanto, 2013) Ukuran perusahaan adalah suatu skala dimana dapat diklasifikasikan besar kecilnya perusahaan menurut berbagai cara (total aktiva, log size, nilai saham dan lain-lain). Ukuran perusahaan digambarkan sebagai ukuran atau besarnya aktiva yang dimiliki oleh perusahaan. Semakin besar perusahaan maka semakin besar juga kegiatan usaha yang dilakukan oleh perusahaan. Dalam penelitian ini dhitung dengan menggunakan log natural, jumlah aset dengan nilai ratusan miliar bahkan triliun akan disederhasanakan tanpa mengubah proporsi dari jumlah aset yang sesungguhnya.

\section{Pertumbuhan Perusahaan}

(Brigham \& Huston, 2010) Pertumbuhan perusahaan adalah perubahan (peningkatan atau penurunan) total aset yang dimiliki oleh perusahaan. Pertumbuhan pada perusahaan sebagai gambaran perbandingan pertumbuhan masa lalu dan masa mendatang. (Purba, 2017) memberikan gambaran bahwa tingkat pertumbuhan suatu perusahaan akan menunjukkan sampai seberapa jauh perusahaan menggunakan hutang sebagai sumber pembiayaannya. Berhubungan dengan leverage, perusahaan yang mempunyai tingkat pertumbuhan yang tinggi disarankan menggunakan ekuitas sebagai sumber pembiayaannya agar tidak terjadi biaya keagenan (agency cost) antara pemegang saham dengan manajemen perusahaan, sedangkan perusahaan dengan tingkat pertumbuhan yang rendah disarankan 
menggunakan hutang karena penggunaan hutang akan mengharuskan perusahaan tersebut membayar bunga secara teratur.

\section{PENGEMBANGAN HIPOTESIS}

\section{Intellecual Capital berpengaruh terhadap kinerja keuangan}

Intellectual Capital adalah substansi tentang intelektual yang telah dirumuskan, mencakup dan diungkap untuk dapat membentuk kekayaan, dengan jalan membentuk suatu aset yang memiliki nilai tinggi (Ulum, 2009) Resources Based Theory (RBT) memiiliki kriteria sebagai sumber daya yang mampu menciptakan keunggulan kompetitif perusahaan sehingga dapat menciptakan nilai bagi perusahaan, RBT meyakini bahwa perusahaan akan mencapai keunggulan jika perusahaan tersebut dapat memanfaatkan sumber daya yang unggul secara efektif fan efisien.

Perusahaan yang memanfaatkan sumber daya secara efektif dan efisien akan meningkatkan nilai tambah bagi perusahaan. Perusahaan memiliki strategi dan menggunakannya untuk mempertahankan dalam menghadapi persaingan bisnis dengan menerapkan sumber daya unggul dan memiliki nilai sehingga meningkatkan kinerja perusahaan menjadi lebih baik. Hal ini didukung oleh penelitian yang dilakukan oleh (Wijayani, 2017), (Yulianto \& Lindawati, 2020), (Muzakar \& Della Ariska, 2018), menyatakan hasil bahwa IC mempunyai pengaruh positif sinifikan terhadap kinerja keruangan perusahaan.

\section{H1 : Intellectual Capital berpengaruh terhadap kinerja keuangan pada perusahaan Pertambahan yang terdaftar di BEI}

\section{Competitive Advantage berpengaruh terhadap kinerja keuangan}

Competitive advantage merupakan salah satu wujud yang dapat perusahaan terapkan dalam menjalankan strategi perusahaan. Perusahaan dapat dikatakan telah mencapai keunggulan bersaing jika perusahaan tersebut menerapkan sebuah strategi untuk menciptakan nilai yang tidak bisa dilakukan oleh perusahaan lain. Competitive advantage dapat dikatakan sebagai jantung dari kinerja perusahaan dalam menghadapi persaingan. Strategi ini memberikan keuntungan bagi perusahaan dalam mencapai kinerja perusahaan menjadi lebih baik dan mampu bersaing secara efektif dan efisien dalam pasar bebas.

Menurut Resources Based Theory (RBT) perusahaan akan mencapai keunggulan jika perusahaan tersebut memiliki sumber daya yang unggul. RBT meyakini bahwa keunggulan bersaing dapat diperoleh dari smber daya yang terdapat pada perusahaan yang mampu mengarahkan perusahaan untuk memiliki kinerja jangka panjang yang baik. Hal ini didukung oleh penelitian yang dilakukan oleh (Muzakar \& Della Ariska, 2018) yang menjelaskan bahwa competitive advantage berhasil memediasi intellectual capital dan financial performance dan (Rochmadhona, Suganda, \& Cahyadi, 2018) menyatakan competitive advantage berpengaruh positif terhadap kinerja keuangan.

\section{$\mathrm{H} 2$ : Competitive Advantage berpengaruh terhadap kinerja keuangan pada perusahaan pertambangan yang terdaftar di BEI}

\section{Struktur Modal berpengaruh terhadap kinerja keuangan}

Struktur modal merupakan bagian dari struktur keuangan yang berkaitan dengan pembelanjaan jangka panjang perusahaan. Struktur modal merupakan perbandingan antara jumlah utang jangka pendek yang bersifat permanen. Struktur modal diukur dengan menggunakan Debt to Equity Ratio (DER) yang menggambarkan kemampuan modal sendiri dalam menjamin tota utang yang dimiliki oleh perusahaan. Rasio ini membandingkan antara seluruh hutang lancar dengan seluruh ekuitas dan akan diketahui jumlah dana yang disediakan peminjam serta dapat mengetahui setiap jumlah modal yang dijadikan jaminan hutang. Hal ini didukung oleh penelitian yang dilakukan oleh (Kristianti, 2018) menyatakan bahwa struktur modal berpengaruh signifikan terhadap kinerja keuangan.

\section{H3 : Struktur modal berpengaruh terhadap kinerja keuangan pada perusahaan pertambangan yang terdaftar di BEI}

\section{Ukuran Perusahaan berpengaruh terhadap kinerja keuangan}

Ukuran perusahaan memiliki pengaruh yang berbeda terhadap pencapaian nilai perusahaan. Perusahaan diklasifikasi sebagai perusahaan besar dan perusahaan kecil, ukuran besar kecilnya perusahaan ditunjukkan oleh nilai dari total aset, total penjualan, total laba, beban pajak dan sebagainya. Menurut (Fitriani, E. and Zamzami, 2018) perusahaan memiliki total aset yang besar maka pihak manajemen lebih leluasa dalam mempergunakan aset yang ada di perusahaan. Hal ini berkaitan dengan agency theory yang mengasumsikan bahwa setiap individu semata-mata termotivasi oleh kepentingan 
dirinya sendiri sehingga menyebabkan konflik kepentingan antara principal dan agent. Hal ini didukung oleh penelitian yang dilakukan oleh (Ula, Sochib, \& Ermawati, 2018) menyatakan bahwa ukuran perusahaan berpengaruh terhadap kinerja keuangan.

\section{H4 : Ukuran Perusahaan berpengaruh terhadap kinerja keuangan pada perusahaan pertambahan yang terdaftar di BEI}

\section{Pertumbuhan Perusahaan berpengaruh terhadap kinerja keuangan}

Pertumbuhan perusahaan dapat memberikan gambaran mengenai perkembangan perusahaan untuk meningkatkan ukuran perusahaan dan sebagai perbandingan di masa lalu. Pertumbuhan perusahaan dikatakan sebagai pertumbuhan total aset dimana pertumbuhan masa lalu akan menggambarkan profitabilitas yang akan datang dan pertumbuhan yang akan datang.

Resources Based Theory (RBT) menjelaskan bahwa kontituitas dan pertumbuhan perusahaan ditentukan oleh adanya pengelolaan dan pengembangan aset-aset yang strategis perusahaan. (Wernefelt, 1984) memberikan gambaran bahwa RBT merupakan sumber daya yang terdapat pada perusahaan yang dapat dijadikan keunggulan bersaing dna mampu mengarahkan perusahaan untuk mempnuai kinerja jangka panjang yang lebih baik. Hal ini didukung oleh penelitian yang dilakukan oleh (Suryahadi, 2018) menyatakan bahwa pertumbuhan perusahaan berpengaruh positif signifikan terhadpa nilai perusahaan.

\section{H5 : Pertumbuhan perusahaan berpengaruh terhadap kinerja keuangan pada perusahaan pertambangan yag terdaftar di BEI}

\section{Kerangka Konseptual}

\section{Gambar 1. Kerangka Konseptual}

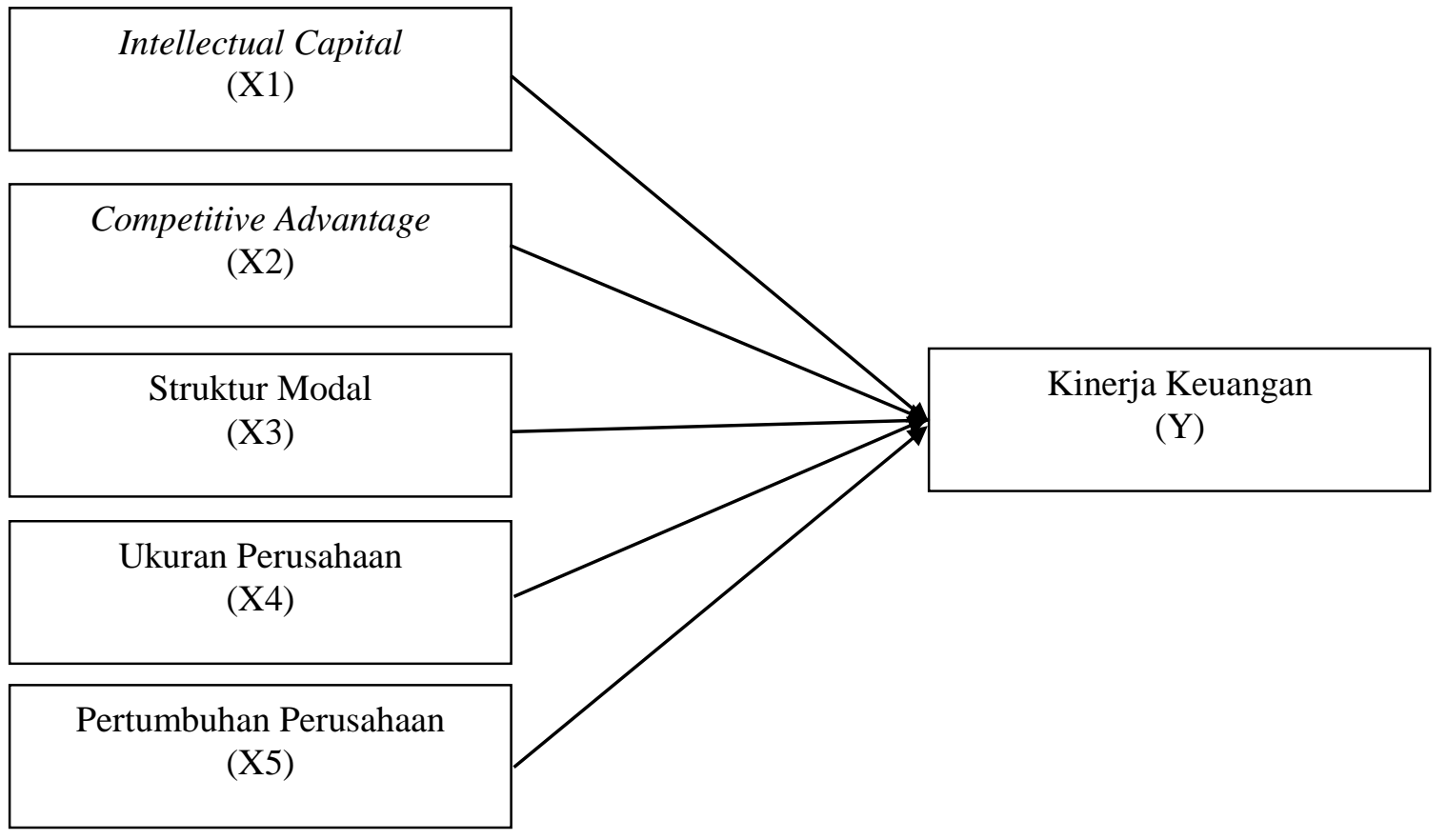

\section{METODE PENELITIAN}

Jenis data yang digunakan dalam penelitian ini merupakan data sekunder yang diperoleh dari Bursa Efek Indonesia (BEI) berupa laporan tahunan dan laporan keuangan perusahaan pertambangan di IDX Statistic pada tahun 2015-2019. Desain penelitian yang digunakan yaitu penelitian asosiatif dengan bentuk hubungan kausal. (Sugiyono, 2017) penelitian asosiatif kausal adalah penelitian yang bertujuan untuk mengetahui hubungan antara dua variabel atau lebih. Populasi dalam perusahaan pertambahan ini ada 47 perusahaan pertambahan high profile yang terdaftar di BEI tahun 2015-2019 dan pengambilan sampel menggunakan teknik non probability sampling dengan teknik purposive sampling dengan pertimbangan tertentu maka sampel yang digunakan sebagai berikut : 
Tabel 1. Penentuan Sampel

\begin{tabular}{lc}
\hline \multicolumn{1}{c}{ Keterangan } & Jumlah \\
\hline Jumlah perusahaan pertambahan high profile yang & 47 \\
terdaftar di BEI tahun 2015-2019 & \\
Data yang tidak berhasil diperoleh di BEI maupun & $(11)$ \\
website perusahaan & 36 \\
Data yang tersedia secra fisik & $(23)$ \\
Data rusak, tidak lengkap danmemenuhi kreoteria & 13 \\
Jumlah data yang digunakan sebagai sampel & \\
\hline
\end{tabular}

Sumber : Diolah Peneliti, 2021

Berdasarkan tabel diatas dapat diketahui bahwa data yang akan digunakan dalam penelitian ini terdapat 13 perusahaan dengan tahun pengamatan 5 tahun sehingga diperoleh sampel 65 laporan keuangan perusahaan. Penelitian ini menggunakan metode analisis data Partial Least Square (PLS) dengan teknik regresi linier berganda. (Ghozali, 2015) PLS dianggap mampu menggambarkan konsep model dengan variabel laten (variable yang tidak dapat diukur secara langsung) akan tetapi diukur melalui indikator-indikator (variabel manifest).

\section{HASIL DAN PEMBAHASAN \\ Analisis Data Uji Statistik Deskriptif}

Tabel 2. Deskriptif Statistik Perusahaan

\begin{tabular}{rccrrrrrrr}
\hline & \multirow{2}{*}{ No. } & \multirow{2}{*}{ Missing } & \multicolumn{1}{c}{ Mean } & Median & \multicolumn{1}{c}{ Min } & Max & $\begin{array}{r}\text { Standard } \\
\text { Deviation }\end{array}$ & $\begin{array}{c}\text { Excess } \\
\text { Kurtosis }\end{array}$ & Skewness \\
\hline X1 & 1 & 0 & 516.385 & 455.000 & 59.000 & 1.473 .000 & 270.630 & 1775 & 1.139 \\
X2 & 2 & 0 & 14.569 & 11.000 & 0.000 & 54.000 & 12.489 & 1.202 & 1.250 \\
X3 & 3 & 0 & 85.738 & 66.000 & 17.000 & 288.000 & 59.891 & 0.965 & 1.244 \\
X4 & 4 & 0 & 1.891 .323 & 1.890 .000 & 1.398 .000 & 2.786 .000 & 321.424 & 10.679 & 3.347 \\
X5.1 & 5 & 0 & 111.815 & -11.000 & -99.000 & 1.708 .000 & 368.424 & 10.679 & 3.347 \\
X5.2 & 6 & 0 & 11.754 & 8.000 & -16.000 & 140.000 & 23.696 & 14.645 & 3.334 \\
Y.1 & 7 & 0 & 1.063 .785 & 862.000 & 2.000 & 3.941 .000 & 895.376 & 1.370 & 1.225 \\
Y.2 & 8 & 0 & 1.701 .815 & 1.321 .000 & 7.000 & 5.525 .000 & 1.284 .071 & 0.607 & 1.013 \\
\hline
\end{tabular}

Sumber : Diolah peneliti, 2021

Tabel 2 diatas menunjukkan bahwa jumlah observasi dari penelitian ini adalah 65. Gabungan antara cross section dan time series, dengan cross section sebanyak 13 perusahaan dan time series selama 5 tahun dari tahun 2015-2019. Sehingga diperoleh jumlah observasi sebayak 65 laporan keuangan perusahaan.

\section{Uji Hipotesis}

Evaluasi Model Pengukuran (Outer Model)

Uji Validitas Konvergen

Tabel 3. Hasil Output Validitas Convergent Smart PLS 3.0

\begin{tabular}{lc}
\hline Competitive Advantage & $\begin{array}{c}\text { Average Variance } \\
\text { Extracted (AVE) }\end{array}$ \\
\hline Intellectual Capital & 1.000 \\
Kinerja Keuangan & 1.000 \\
Pertumbuhan Perusahaan & 0,983 \\
Struktur Modal & 1.000 \\
Ukuran Perusahaan & 1.000 \\
\hline Sumber : Diolah peneliti, 2021 & 1.000 \\
\hline
\end{tabular}

Tabel 3 diatas hasil pengujian menunjukkan bahwa nilai AVE diatas memiliki nilai lebih besar dari 0,5 maka dapat dikatakan valid. 


\section{Uji Validitas Diskriminan}

Tabel 4. Hasil Output Validitas Discriminant Smart PLS 3.0

\begin{tabular}{lrrrrrr}
\hline & $\begin{array}{c}\text { Competitive } \\
\text { Advantage }\end{array}$ & $\begin{array}{c}\text { Intellectual } \\
\text { Capital }\end{array}$ & $\begin{array}{c}\text { Kinerja } \\
\text { Keuangan }\end{array}$ & $\begin{array}{c}\text { Pertumbuhan } \\
\text { Perusahaan }\end{array}$ & $\begin{array}{c}\text { Struktur } \\
\text { Modal }\end{array}$ & $\begin{array}{c}\text { Ukuran } \\
\text { Perusahaan }\end{array}$ \\
\hline X1 & 0.720 & 1.000 & 0.721 & 0.025 & -0.175 & -0.066 \\
X2 & 1.000 & 0.720 & 0.992 & 0.083 & -0.462 & -0.223 \\
X3 & -0.462 & -0.175 & -0.452 & 0.201 & 1.000 & 0.612 \\
X4 & -0.223 & -0.066 & -0184 & 0,057 & 0.612 & 1.000 \\
X5 & 0.083 & 0.025 & 0.072 & 1.000 & 0.201 & 0.057 \\
Y.1 & 0.989 & 0.690 & 0.991 & 0.052 & -0.511 & -0.222 \\
Y.2 & 0.977 & 0.739 & 0.991 & 0.091 & -0.385 & -0.143 \\
\hline
\end{tabular}

Sumber : Diolah peneliti, 2021

Tabel 4 diatas menunjukan masing-maisng cross loading yang ada pada variabel lainnya, sehingga indikator tersebut dapat dikatakan memenuhi discriminant validity atau dikatakan valid.

\section{Uji Reliabilitas}

Tabel 5. Hasil Output Uji Reliabilitas Smart PLS 3.0

\begin{tabular}{lcc}
\hline & Cronbach's Alpha & Composite Reliability \\
\hline Competitive Advantage & 1.000 & 1.000 \\
Intellectual Capital & 1.000 & 1.000 \\
Kinerja Keuangan & 0.983 & 0.983 \\
Pertumbuhan Perusahaan & 1.000 & 1.000 \\
Struktur Modal & 1.000 & 1.000 \\
Ukuran Perusahaan & 1.000 & 1.000
\end{tabular}

Sumber : Diolah peneliti, 2021

Tabel 5 diatas menunjuukan nilai cronbach's alpha dan composite reliability diatas 0,70 menunjukkan bahwa reabilitas alat ukur yang tinggi berarti bahwa pengukur dari masing-masing konstruk berkorelasi tinggi.

\section{Evaluasi Model Struktural (Inner Model)} Uji R Square $\left(\mathbf{R}^{2}\right)$

Tabel 6. Hasil Output R Square Smart PLS 3.0

\begin{tabular}{lcc}
\hline & R Square & R Square Adjusted \\
\hline Kinerja Keuangan & 0,985 & 0,984 \\
\hline Sumber : Diolah peneliti, 2021 & &
\end{tabular}

Tabel 6 diatas menunjukkan hasil nila $R$ Square $\left(R^{2}\right)$ kinerja keuangan yaitu 0,985 yang berarti presentasi besarnya pengaruh intellectual capital, competitive advantage, struktur modal, ukuran perusahaan dan pertumbuhan perusahaan terhadap kinerja keuangan sebesar 98,5\% dan sisanya 1,5\% dijelaskan oleh variabel lain yang tidak terdapat di penelitian ini.

\section{Uji Koefisien Path}

Tabel 7. Hasil Ouput Path Coefficient Smart PLS 3.0

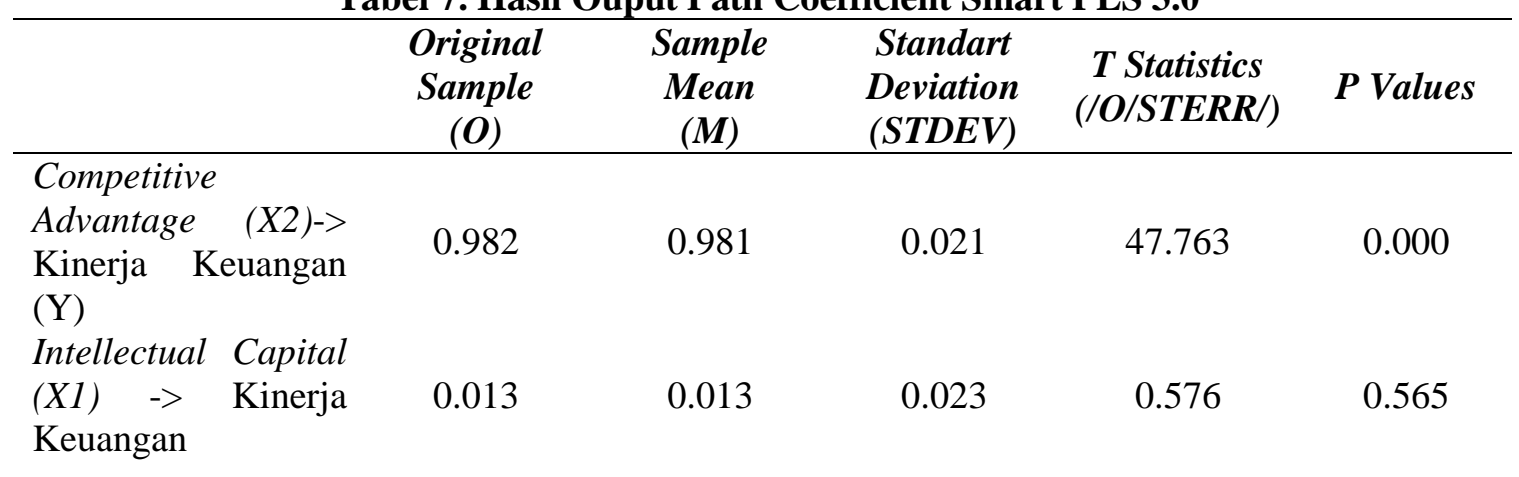




$\begin{array}{llllll}\begin{array}{l}\text { Pertumbuhan } \\ \text { Perusahaan (X5) } \\ \text { Kinerja Keuangan } \\ \text { (Y) }\end{array} & -0.007 & -.0 .004 & 0.021 & 0.351 & 0.231 \\ \begin{array}{l}\text { Struktur Modal (X3) } \\ ->\quad \text { Kinerja }\end{array} & -0.026 & -0.028 & 0,022 & 1.200 & 0.231 \\ \begin{array}{l}\text { Keuangan (Y) } \\ \text { Ukuran Perusahaan } \\ (\mathrm{X} 4)->\quad \text { Kinerja }\end{array} & 0.052 & 0.054 & 0.017 & 3.134 & 0.002 \\ \text { Keuangan (Y) }\end{array}$

Sumber : Diolah peneliti, 2021

Tabel 7 diatas menunjukkan bahwa koefisien path nilai T- Statistic $>1.96$ maka dapat disimpulkan hipotesis berpengaruh dignifikan dan jika diperoleh T-statistic $<1.96$ maka disimpulkan tidak berpengaruh signifikan. Hal tersebut pada intellectual capital, struktur modal dan pertumbuhan perusahana tidak berpengaruh terhadap kinerja perusahaan, tetapi competitive advantage dan ukuran perusahaan berpengaruh terhadap kinerja perusahaan.

\section{PEMBAHASAN}

Intellectual Capital tidak berpengaruh terhadap kinerja keuangan, hal ini dikarenakan perusahaan tidak dapat memanfaatkan sumber daya yang dimilikinya dengan optimal. Pemanfaat human capital sebagai modal karyawan yang berupa biaya karyawan yang diukur melalui beban yang dkeluarkan perusahaan berupa gaji dan tunjangan tidak dikelola secara baik. Hasil penelitian ini tidak didukung oleh teori RBT karena sumber daya yang dimiliki perusahaan belum menjadi prioritas penting untuk mengarahkan perusahaan agar memiliki kinerja jangka panjang yang baik. Penelitian ini tidak sejalan dengan penelitian (Rochmadhona et al., 2018), (Wijayani, 2017) dan (Kurniawati, Rasyid, \& Setiawan, 2020) yang menyatakan bahwa intellectual capital tidak berpengaruh terhadap kinerja keuangan.

Competitive Advantage berpengaruh terhadap kinerja keuangan, hal ini perusahaan mampu menciptakan dan mempertahankan keunggulan bersaing secara continue terbukti akan meningkatkan kinerja keuangan. dengan ini investor dapat mempertimbangkan bagaimana kekuatan dan kemampuan perusahaan memberikan nilai pengembalian modal yang tinggi dan perusahaan akan terus berusaha meningkatkan performa bisnisnya untuk menarik investor melalui keunggulan bersaing. Hasil penelitian ini didukung teori RBT yaitu keunggulan bersaing yang dimiliki perusahaan mampu mengarahkan perusahaan untuk memiliki kinerja jangka panjang yang baik. Penelitian ini sejalan dengan (Rochmadhona et al., 2018) menyatakan competitive advantage berpengaruh terhadap kinerja keuangan.

Struktur Modal tidak berpengaruh terhadap kinerja keuangan, hal ini dikarenakan adanya oeningatkan struktur modal cenderung tidak meningkatkan kinerja keuangan pada perusahaan, karena adanya peningkatan hutang perusahaan akan menajdi tambahan beban bagi perusahaan dan berimbas pada melemahnya kinerja keuangan perusahaan. Perusahaan yang memiliki nilai DER yang tinggi mencerminkan risiko perusahaan yang relatif tinggi, sehingga hal tersebut menjadi pertimbangan bagi para investor untuk berinvestasi. Hasil penelitian ini tidak mendudukung teori agensi karena perusahaan memiliki kepentingan sendiri untuk mengoptimalkan modal perusahaan sedangkan principal dalam hal ini investor menginginkan pengembalian modal yang tinggi. Penelitian ini tidak sejalan dengan penelitian (Kristianti, 2018) yang menyatakan struktur modal berpengaruh terhadap kinerja keuangan.

Ukuran perusahaan berpengaruh terhadap kinerja keuangan, hal ini kinejra perusahaan sebagai salah satu kualitas pencapaian keuangan perusahaan yang didasarkan pada efektifitas dalam menghasilkan laba dapat diperngaruhi langsung oleh total aset yang dimiliki perusahaan. Total aset yang dimiliki perusahaan dapat digunakan untuk memprediksi maupun menjelaskan dari kinerja keuangan perusahaan. Hasil ini mendukung teori agensi karena perusahaan mampu mempertahankan danmengoptimalkan pengelolaan aset untuk mendapatkan laba dan principal dalam hal ini investor akan mendapatkan keuntungan. Penelitian ini sejalan dnegan penelitian (Ula et al., 2018) yang menyatakan ukuran perusahaan berpengaruh terhadap kinerja keuangan.

Pertumbuhan perusahaan tidak berpengaruh terhadap kinerja keuangan, hal ini karena perusahaan terfokus pada memaksimalkan perolehan laba, pertumbuhan perusahaan dalam penelitian ini tidak dapat 
dijadikan tolak ukur kinerja keuangan pada perusahaan karena kenaikan aset terjadi ketika perusahaan menambah aset tetapnya sehingga menimbulkan biaya yang menjadikan kurangnya laba pada perusahaan. Hasil penelitian ini tidak mendukung teori agensi karena perusahaan yang berusaha mengoptimalkan kenaikan aset tetapi tidak dapat mempengaruhi kinerja keuangan perusahaan. Penelitian ini tidak sejalan dengan penelitian (Purwanto \& Marsono, 2017) yang menyatakan pertumbuhan perusahaan berpengaruh terhadap kinerja keuangan.

\section{KESIMPULAN}

Pada penelitian ini dapat disimpulkan bahwa Intellectual capital tidak berpengaruh terhadap kinerja keuangan, Competitive advantage berpengaruh terhadap kinerja keuangan, Struktur modal tidak berpengaruh terhadap kinerja keuangan, Ukuran perusahaan berpengaruh terhadap kinerja keuangan, dan Pertumbuhan perusahaan tidak berpengaruh terhadap kinerja perusahaan pertambangan yang terdaftar di Bursa Efek Indonesia Tahun 2015-2019.

\section{SARAN}

1. Saran Praktis : Bagi manajemen perusahaan diharapkan untuk memperkuat intellectual capital, struktur modal dan pertumbuhan perusahaan agar dapat berkontribusi tinggi terhadap perusahaan agar investor dapat mempertimbangkan dalam pengambilan keputusan dan meningkatkan nilai laba pada perusahaan. Serta tetap mempertahankan dan meningkatkan kualitas competitive advantage dan ukuran perusahaan agar para investor tertarik dalam menanamkan modalnya.

2. Saran Teoritis : Bagi peneliti berikutnya diharapkan dapat menambah variabel lain seperti nilai perusahaan, jumlah sampel dan tahun pengamatan dan dikembangkan ke perusahaan-perusahaan yang lain agar hasilnya lebih kompetitif.

\section{REFERENSI}

Barney, J. B. (2010). Gaining and Sustaining Competitive Advantage (Fourth Edi). Addison Wesley, Massachusetts.

Brigham \& Huston. (2010). Financial Manajemen Dasar - Dasar Manajemen Keuangan (Terjemah). Jakarta: Salemba Empat.

Cheng, M. Y., Lin, J. Y., Hsiao, T. Y., \& Lin, T. W. (2010). Invested resource, competitive intellectual capital, and corporate performance. Journal of Intellectual Capital, 11(4), 433-450. https://doi.org/10.1108/14691931011085623

Dimas, A. (2020). Intip Kinerja Tiga Emiten Batubara Ini Dalam Lima Tahun Terakhir. Retrieved June 5, 2021, from insight.kontan.co.id website: https://insight.kontan.co.id/news/intip-kinerja-tigaemiten-batubara-ini-dalam-lima-tahun-terakhir?page=all

Fahmi, I. (2017). Analisis Laporan Keuangan. Bandung: Alfabeta.

Fitriani, E. and Zamzami, Z. (2018). Analisis Pengaruh Ukuran Perusahaan, Leverage dan Good Corporate Governance Terhadap Kinerja Keuangan (Studi Kasus Perusahaan Sektor Utama di Bursa Efek Indonesia Tahun 2011-2016). Jurnal Akuntansi \& Keuangan Unja, 3, 14-24.

Ghozali, I. dan H. L. (2015). Konsep, Teknik, Aplikasi Menggunakan Smart PLS 3,0 untuk Penelitian Empiris. Semarang: BP UNDIP.

Jensen, M., C., dan W. M. (1976). Theory of the firm : Managerial behavior, agency cost and ownership structure. Journal of Finance Economic, 3, 305-360. Retrieved from http://www.nhh.no/for/courses/spring/eco420/jensenmeckling-76.pdf

Jogiyanto, H. (2013). Teori Portofolio dan Analisis Investasi (Keempat). Yogyakarta: BPFE Yogyakarta.

Kristianti, I. P. (2018). Analisis Pengaruh Struktur Modal Terhadap Kinerja Keuangan Perusahaan. Akuntansi Dewantara, Vol. 2 No.

Kurniawati, H., Rasyid, R., \& Setiawan, F. A. (2020). Pengaruh Intellectual Capital Dan Ukuran Perusahaan. Jurnal Muara Ilmu Ekonomi Dan Bisnis, 4(1), 64-76.

Munawir, S. (2012). Analisis Informasi Keuangan. Yogyakarta: Liberty.

Muzakar, I., \& Della Ariska, D. (2018). Analisis Pengaruh Intellectual Capital Terhadap Financial Performance Dengan Competitive Advantage Sebagai Variabel. Benefit Jurnal Manajemen Dan Bisnis, 3(2), 31-38.

Porter, M. E. (2007). Competitive Advantage. New York: The Free Pres. 
Purba, D. H. P. (2017). Pengaruh Pertumbuhan Perusahaan Dan Kebijakan Struktur Modal Terhadap Perubahan Harga Saham Pada Perusahaan Property Dan Real Estate Di Bei. Jurnal Akuntansi Dan Keuangan Methodist, 1, 19-31.

Purwanto, D., \& Marsono, A. D. (2017). Pengaruh Struktur Modal Dan Pertumbuhan Perusahaan Terhadap Nilai Perusahaan Dengan Kinerja Perusahaan Sebagai Variabel Intervening. Jurnal Riset Perbankan Manajemen Dan Akuntansi, Vol. 1 No.

Rochmadhona, B. N., Suganda, T. R., \& Cahyadi, S. (2018). The Competitive Advantage between Intellectual Capital and Financial Performance of Banking Sector in ASEAN. Jurnal Keuangan Dan Perbankan, 22(2), 321-334. https://doi.org/10.26905/jkdp.v22i2.2060

Sucipto. (2003). Penilaian Kinerja Keuangan. In Jurnal Akuntansi Universitas Sumatera Utara. Sumatera Utara: Digital Library.

Sudana, I. M. (2015). Manajemen Keuangan Perusahaan (Kedua). Jakarta: Erlangga.

Sugiyono. (2017). Metode Penelitian Kuantitatif, Kualitatif dan R\&D. Bandung: Alfabeta.

Suryahadi, A. (2018). Sepanjang 2019 Sektor Pertambangan Turun Drastis. Retrieved from https://investasi.kontan.co.id/news/sepanjang-2019-sektor-pertambangan-turun-drastis-beginiprospeknya-di-2020?page $=2$

Ula, F., Sochib, \& Ermawati, E. (2018). Pengaruh Ukuran Perusahaan Dan Stuktur Kepemilikan Publik Terhadap Kinerja Keuangan Pada Perusahaan Manufaktur Sektor Industri Barang Konsumsi Yang Terdaftar Di BEI. Progress Conference Vol. 1, No. 1, 1(1), 861-869. Retrieved from https://scholar.google.com/

Ulum, I. (2009). Intellectual Capital : Konsep dan Kajian Empiris. Yogyakarta: Graha Ilmu.

Wernefelt, B. (1984). A resource-based view of the firm. Strategic Management Journal, 5 (2), 171180.

Wiagustini, L. P. (2010). Dasar - dasar Manajemen Keuangan. Denpasar: Udayana University Press.

Wijayani, D. R. (2017). PENGARUH INTELLECTUAL CAPITAL TERHADAP KINERJA KEUANGAN PERUSAHAAN PUBLIK DI INDONESIA (Studi Empiris Pada Perusahaan Manufaktur di BEI 2012-2014). Jurnal Riset Akuntansi Dan Bisnis Airlangga, 2(1), 97-116. https://doi.org/10.31093/jraba.v2i1.23

Wiyono, Gendro dan Kusuma, H. (2017). Manajemen Keuangan Lanjutan Berbasis Corporate Value Creation Edisi Kesatu. Yogyakarta: UPP STIM YPKN.

Yulianto, Y., \& Lindawati, L. (2020). "Pengaruh Intellectual Capital Terhadap Kinerja Keuangan Perusahaan Yang Tergabung Dalam Jakarta Islamic Index.” JURNAL SeMaRaK, 3(3), 29. https://doi.org/10.32493/smk.v3i3.7098 